\title{
An Analysis of Learning Difficulties on Mathematic at Elementary School
}

\author{
Muh. Yazid*, Atiaturrahmaniah, Mita Armila \\ Universitas Hamzanwadi Lombok Timur, Indonesia
}

Corresponding Author: Yazid, $\otimes$ muhyazid@hamzanwadi.ac.id*

\begin{tabular}{|c|c|}
\hline \multirow[b]{2}{*}{$\begin{array}{c}\text { ARTICLE INFO } \\
\text { Article history: } \\
\text { Received } \\
\text { October 27, } 2020 \\
\text { Revised } \\
\text { November 23, } \\
2020 \\
\text { Accepted } \\
\text { November 25, } \\
2020\end{array}$} & ABSTRACT \\
\hline & $\begin{array}{l}\text { This article aims at finding out the factors of Mathematic learning the } \\
\text { difficulty of class } \mathrm{v} \text { at Elementary School in Melati cluster kerumut } \\
\text { village academic year } 2020 / 2021 \text {. This study was a qualitative descriptive } \\
\text { study. The population of this study was class V students in melati cluster } \\
\text { kerumut village such as SDN } 1 \text { Kerumut, SDN } 2 \text { Kerumut, and SDN } 3 \\
\text { Kerumut. The sample of this study was selected based on the students' } \\
\text { test result which was on low category. The technique of the data } \\
\text { collection used interview and documentation. The result showed that } \\
\text { students mathematic learning difficulties affected by internal and } \\
\text { external factor of students. }\end{array}$ \\
\hline & $\begin{array}{l}\text { Keywords: Learning Difficulties, Learning Mathematic, Difficulties Factor in } \\
\text { Learning }\end{array}$ \\
\hline ow to cite & $\begin{array}{l}\text { Yazid, M., \& Atiaturrahmaniah, A., \& Armila, M. (2020). An Analysis of } \\
\text { Learning Difficulties on Mathematic at Elementary School. IJoASER } \\
\text { (International Journal on Advanced Science, Education, and Religion), 3(3). 135-141. } \\
\text { https://doi.org/10.33648/ijoaser.v3i3.84 } \\
\text { https://ojs.staialfurqan.ac.id/IJoASER/ }\end{array}$ \\
\hline 然 & https://creativecommons.org/licenses/by-sa/4.0/ \\
\hline
\end{tabular}

\section{INTRODUCTION}

Mathematics lessons, where most of the content is real, not a few students find it difficult to learn. This must receive special attention from several parties, such as teachers, the school environment, student guardians, and the surrounding environment because mathematics is one of the compulsory subjects that all levels from elementary to secondary level must learn (Niess, 2005; Yazid et al., 2020; Artigue, 2002). Learning mathematics will train students to think logically and analytically. This is very useful for the problem-solving process in the course of his life (Schoenfeld, 2016). Therefore, students' learning difficulties (LD) of mathematics must be quickly recognized and overcome. Learning difficulties and learning problems are terms that describe a student starting to experience learning difficulties at school (Treagust et al., 2000). States that learning difficulties are a general term for various types of difficulties in listening, speaking, reading, writing, and counting (Khan, 2011). This condition is not due to physical or mental disabilities, nor is it due to environmental factors, but because of the difficulty of the individual himself when processing information on the object he is studying (Schoenfeld, 2016).

Students who experience learning difficulties will find it difficult to understand the subject matter delivered by the teacher so that students will be lazy in learning (Palloff \& Pratt, 1999; Sirhan, 2007). Also, students cannot master the material, even avoid lessons, ignore assignments given by the teacher, so that learning scores decrease 
and learning achievement is low. Students' learning difficulties in mathematics are not because they are unable to learn, but certain conditions make them not ready to learn (Acharya, 2017; Mundia, 2017). There are quite a lot of students who have high intelligence, but their learning outcomes are low, far from what is expected (MelbyLervåg et al., 2016). Therefore, it is necessary to have stepped in analyzing the difficulties experienced by students so that problem-solving steps can be taken. By knowing the factors of student learning difficulties, of course, the teacher can create and prepare effective and efficient mathematics learning with appropriate learning methods. Students who experience learning difficulties will cause symptoms of various learning difficulties (Hong, 2015). Experiencing learning difficulties indicates failure in achieving learning goals. The following is a summary of the math results of the fifthgrade students of the Melati Cluster, Kerumut Village, Pringgabaya District:

Table 1. Mathematics test results for class V of the Melati Cluster in Kerumut Village.

\begin{tabular}{|c|c|c|c|c|}
\hline \multirow[t]{2}{*}{ Name of School } & \multirow{2}{*}{$\begin{array}{l}\text { Number of } \\
\text { Students } \\
\text { Class V }\end{array}$} & \multirow{2}{*}{$\begin{array}{c}\text { Minimum } \\
\text { completeness } \\
\text { criteria }\end{array}$} & \multicolumn{2}{|c|}{ Student Information } \\
\hline & & & Complete & Not Complete \\
\hline SDN 1 Kerumut & 25 Students & 60 & 14 & 11 \\
\hline SDN 2 Kerumut & 39 Students & 60 & 24 & 15 \\
\hline SDN 3 Kerumut & 22 Students & 60 & 12 & 10 \\
\hline amount & 86 & & 50 & 36 \\
\hline
\end{tabular}

Based on an interview on February 28, 2020, a teacher who taught in class V stated that mathematics is a difficult subject, especially when it comes to calculating. There are 3 aspects of difficulties experienced by students, namely understanding concepts, skills, problem-solving. Students do not understand the concept of learning mathematics because students do not understand the material described, students lack numeracy skills in mathematics learning, students lack problem-solving to the material presented by the teacher. Teachers should be able to choose strategies or learning models that are appropriate and in accordance with the expected learning objectives so that they can improve students' abilities in learning (Asrial et al., 2019). As we know that the learning process is very influential on the results of student abilities, therefore it is necessary to have learning that can activate students and try to find out for themselves (Scheffer et al., 2017). The factors that cause learning difficulties can be classified into two groups, namely:

a. Internal factors (factors from within humans themselves)

Physiological factors, Physiological factors are factors related to the physical condition of an individual. During the learning process, the role of physiological functions in the human body greatly affects learning outcomes, especially the five senses. The five senses that function properly will facilitate learning activities well too. The five senses that have a big role in learning are the eyes and ears. Example: Psychomotor (the realm of initiative), such as disruption of the students' visual and hearing sensory organs (Grof, 2016). 
Psychological factors, Psychology is the study of human behavior, mental function, and mental processes through scientific procedures. Psychological factors are a person's psychological state that can affect learning (Langer et al., 2017). Example: Cognitive (the realm of copyright) such as low intellectual / intellectual capacity of students, and affective (the realm of sense) such as emotional instability and student attitudes.

b. External factors (factors from outside humans)

Non-social factors, Non-social (physical) factors that exist in the family environment, for example, disharmony in the relationship between father and mother, and the low economic life of the family (Morgan \& Gayer-Anderson, 2016). Non-social in the school environment, for example, learning tools of low quality. Social factors, Social factors are factors that are influenced by the people around students. Example: The community is like a naughty playmate (Sugiharta \& Sudarsana, 2017).

Research on mathematics learning difficulties has been widely carried out, including research conducted by Geri Syahril Sidik and Agus Ahmad Wakih (2019) which is a qualitative descriptive study. The results showed that the difficulty of elementary school students learning mathematics in integer operations was that students had difficulty understanding the purpose of the questions so that they were mistranslated into math sentences. Students have difficulty operating numbers that contain negative signs. $95 \%$ of students have difficulty understanding the meaning of the equal sign $(=)$. And students have difficulty carrying out the distribution operation.

This study examines the learning difficulties experienced by elementary school students in mathematics, especially for integer material related to understanding story problems, and performs arithmetic operations on integers with different signs and divisions. Based on the results of research that has been carried out related to the analysis of learning difficulties in mathematics, research was conducted on: Analysis of the difficulty of learning mathematics for grade $\mathrm{V}$ students of the Kerumut Village Melati Cluster in the Academic Year 2020/2021 ". The purpose of this study was to determine the factors causing the difficulty of learning mathematics in grade $\mathrm{V}$ in elementary schools in the complex village jasmine cluster in the 2020/2021 school year.

\section{METHOD}

This research uses descriptive qualitative research methods. This study aims to determine the factors causing the difficulty of learning mathematics experienced by students, as well as to reveal solutions that can be done to overcome the difficulties in learning mathematics in class $\mathrm{V}$ of the elementary school cluster jasmine, Kerumut village.

Qualitative research methods are research methods based on the philosophy of postpositivism, used to examine natural objects, where the researcher is a key instrument, data collection techniques are carried out in a combination, data analysis is inductive/qualitative, and the results of qualitative research emphasize meaning rather than generalization (Rahi, 2017).

This research was conducted at the elementary school cluster jasmine, Kerumut Village, Pringgabaya District, East Lombok Regency. This research will be conducted in August-September. This research requires a data source to provide information about the problem under study. So data sources are needed, namely the fifth-grade elementary school students of the Kerumut village cluster jasmine who have difficulty learning mathematics and the fifth-grade teachers of the elementary school cluster jasmine, Kerumut village. 
Data collection techniques are the most strategic step in research because the main purpose of the research is to get data. In this study the data were obtained from various sources, using the collection techniques, namely documentation, and interviews. The data analysis used was data reduction, data presentation, and conclusion drawing/verification.

\section{RESULT AND DISCUSSION}

Based on the results of the analysis of interviews conducted by researchers to 18 respondents who were people who were seen in a learning activity, it showed that several factors caused the difficulty of learning mathematics in grade $\mathrm{V}$ elementary school in the complex village jasmine cluster in the 2020/2021 school year, namely because it was influenced by internal factors and external factors.

1) Learning difficulties caused by external factors

External factors that cause students to experience difficulties in learning mathematics in this case are seen from the student's school environment. These factors are a) teachers' teaching style that dominates too much; b) difficulty in selecting and using media that is appropriate to the material being taught, especially for mathematics. Also, there are positives made by the teacher, namely the teacher pays attention to the readiness of students in receiving the mathematics lessons that are delivered, when the students look a little sleepy the teacher encourages students by telling short stories, then with appropriate national/compulsory songs related to learning.

An external factor that comes from the family is that most of the students' parents never help them with math tasks even though they live with their parents. This is due to the limited knowledge of the parents and the low education of the parents so that they are not biased to guide children in learning and completing school assignments given by the teacher. Besides that, some parents are busy working outside, especially those who are farmers, laborers, and construction workers. When they came home they were so tired that they couldn't accompany their children in learning.

2) Learning difficulties caused by internal factors

Based on the results of interviews with students, it was found that students were indeed experiencing difficulties in learning mathematics. It could be seen from the student's internal factors, namely students' knowledge of fraction count operations, speed and discharge, scale, building space, data collection, and presentation, students did not know it at all. And also the statement of the students' thoughts who think that mathematics is a difficult subject, complicated, boring, many calculations, lots of numbers, and children do not like learning formulas.

Based on the results of the above discussion, it was found that external factors, especially the family environment, also influence the causes of students having difficulty learning mathematics because family is the main foundation. Good children's development is certainly based on a good family upbringing. Because students are not directed and assisted by their parents doing their math homework and respondents also do not take math lessons until adulthood their thoughts will still consider mathematics a difficult, complicated, boring subject and the child has no interest in learning or deepening knowledge of mathematics. To overcome the difficulties that come from internal students, it is necessary to instill strong and correct concepts in students from low grades. This finding was aline with Rahman, that need a good skill to overcome the mathematic lesson, students must master arithmetic operations in mathematics well, the teacher must be able to create fun and varied learning, 
integrating several games in mathematics depending on the material to be taught (Rahman, 2017). If possible, students are given math lessons. The finding research was different from conducting by Geri Syahril Sidik \& Agus Ahmad Wakih (2019), resuted that the difficulty of elementary school students learning mathematics in integer operations was that students had difficulty understanding the purpose of the questions so that they were mistranslated into math sentences. Students have difficulty operating numbers that contain negative signs (Sariningtias et al., 2020). 95\% of students have difficulty understanding the meaning of the equal sign (=). And students have difficulty carrying out the distribution operation.

\section{CONCLUSIONS}

Based on the results of research and discussion, it can be concluded that there are students in class $\mathrm{V}$ of the elementary school of the Jasmine Village cluster in the village of Hassut in the academic year 2020/2021 who have a value below the Minimum completeness criteria, which is below 60 . So that student is declared having difficulty learning mathematics and digging deeper information and there are 18 students who really having trouble learning math. The material that is considered difficult is the operation of counting fractions, velocity, and discharge, scale, building space. The factors causing the difficulty of learning mathematics in grade $\mathrm{V}$ elementary school of the complex village jasmine cluster are derived from internal factors of students (factors from within the students themselves), namely knowledge of less mastered mathematics material, then interest in learning mathematics, and thinking assume that mathematics is difficult, complicated, boring, many calculations and many formulas. External factors (factors from outside the student) are also the cause of students' mathematics learning difficulties. These external factors include all situations and conditions in the surrounding environment that do not support student learning activities, especially in the student's family environment. Parents pay less attention to student learning activities, parents never help students do or help complete homework, and students are not included in math lessons

\section{ACKNOWLEDGEMENTS}

Thanks to the Chancellor of Hamzanwadi University, dean of the faculty of education, and head of the primary school teacher education study program for the guidance and motivation given to the author in compiling and completing this research. And thank you also to the authors for your input for the smooth running and improvement of this article.

\section{AUTHOR CONTRIBUTION STATEMENTS}

Muh. Yazid (MY) is the main author of this article, Atiaturrahmaniah (A) helps analyze and evaluate this research before submitting it to the journal for publication, Mita Armila (MA) assists in compiling and collecting research data.

\section{REFERENCES}

Acharya, B. R. (2017). Factors affecting difficulties in learning mathematics by mathematics learners. International Journal of Elementary Education, 6(2), 815.Google Scholar

Artigue, M. (2002). Learning mathematics in a CAS environment: The genesis of a reflection about instrumentation and the dialectics between technical and conceptual work. International Journal of Computers for Mathematical Learning, 7(3), 
245. https:// doi.org/10.1023/A:1022103903080

Asrial, A., Syahrial, S., Kurniawan, D. A., Subandiyo, M., \& Amalina, N. (2019). Exploring Obstacles in Language Learning among Prospective Primary School Teacher. International Journal of Evaluation and Research in Education, 8(2), 249-254. Google Scholar

Grof, S. (2016). Realms of the human unconscious: Observations from LSD research. Souvenir Press. Google Scholar

Hong, B. S. S. (2015). Qualitative analysis of the barriers college students with disabilities experience in higher education. Journal of College Student Development, 56(3), 209-226. https:// doi.org/10.1353/csd.2015.0032

Khan, I. A. (2011). Learning difficulties in English: Diagnosis and pedagogy in Saudi Arabia. Educational Research, 2(7), 1248-1257. Google Scholar

Langer, Á. I., Schmidt, C., Mayol, R., Díaz, M., Lecaros, J., Krogh, E., Pardow, A., Vergara, C., Vergara, G., \& Pérez-Herrera, B. (2017). The effect of a mindfulnessbased intervention in cognitive functions and psychological well-being applied as an early intervention in schizophrenia and high-risk mental state in a Chilean sample: study protocol for a randomized controlled trial. Trials, 18(1), 1-9. https:// doi.org/10.1186/s13063-017-1967-7

Melby-Lervåg, M., Redick, T. S., \& Hulme, C. (2016). Working memory training does not improve performance on measures of intelligence or other measures of "far transfer" evidence from a meta-analytic review. Perspectives on Psychological Science, 11(4), 512-534. https:/ / doi.org/10.1177\%2F1745691616635612

Morgan, C., \& Gayer-Anderson, C. (2016). Childhood adversities and psychosis: evidence, challenges, implications. World Psychiatry, 15(2), 93-102. https:// doi.org/10.1002/wps.20330

Mundia, L. (2017). The assessment of math learning difficulties in a primary grade- 4 child with high support needs: Mixed methods approach. International Electronic Journal of Elementary Education, 4(2), 347-366. Google Scholar

Niess, M. L. (2005). Preparing teachers to teach science and mathematics with technology: Developing a technology pedagogical content knowledge. Teaching and Teacher Education, 21(5), 509-523. https:/ / doi.org/10.1016/j.tate.2005.03.006

Palloff, R. M., \& Pratt, K. (1999). Building learning communities in cyberspace (Vol. 12). San Francisco: Jossey-Bass.

Rahi, S. (2017). Research design and methods: A systematic review of research paradigms, sampling issues and instruments development. International Journal of Economics \& Management Sciences, 6(2), 1-5. Google Scholar

Rahman, A., Sukinnah, E., Shahrill, M., Abbas, N. A., \& Tan, A. (2017). Developing Students' Mathematical Skills Involving Order of Operations. International Journal of Research in Education and Science, 3(2), 373-382. Google Scholar

Sariningtias, R., Kusumawardani, N., Yasfi, A., \& Syafaat, A. (2020, April). Difficulty Analysis Learning Mathematics Society and Factors Cause for Junior Secondary Students. In Proceeding International Conference on Science and Engineering (Vol. 3, pp. 635-638). Google Scholar

Scheffer, I. E., Berkovic, S., Capovilla, G., Connolly, M. B., French, J., Guilhoto, L., Hirsch, E., Jain, S., Mathern, G. W., \& Moshé, S. L. (2017). ILAE classification of the epilepsies: position paper of the ILAE Commission for Classification and Terminology. Epilepsia, 58(4), 512-521. https:// doi.org/10.1111/epi.13709

Schoenfeld, A. H. (2016). Learning to think mathematically: Problem solving, metacognition, and sense making in mathematics (Reprint). Journal of 
Education, 196(2), 1-38.Sirhan, G. (2007). Learning difficulties in chemistry: An overview. https:// doi.org/10.1177\%2F002205741619600202

Sidik, G. S., \& Wakih, A. A. (2020). Kesulitan Belajar Matematik Siswa Sekolah Dasar Pada Operasi Hitung Bilangan Bulat. Naturalistic : Jurnal Kajian Penelitian Pendidikan Dan Pembelajaran, 4(1), 461-470. https:// doi.org/10.35568/naturalistic.v4i1.633

Sugiharta, I. P. S. O., \& Sudarsana, I. K. (2017). Hypnotic Learning Characteristics On Sisya Brahmakunta Community In Denpasar. Vidyottama Sanatana: International Journal of Hindu Science and Religious Studies, 1(2), 132-145. http:/ / dx.doi.org/10.25078/ijhsrs.v1i2.317

Treagust, D., Nieswandt, M., \& Duit, R. (2000). Sources of students difficulties in learning chemistry. Educación Química, 11(2), 228-235. http:/ / dx.doi.org/10.22201/ fq.18708404e.2000.2.66458

Yazid, M., Safitri, L. A. D., \& Jauhari, S. (2020). Diagnosa Kesulitan Belajar Matematika Siswa Kelas V MI NW Pancor Kopong NTB. Prima Magistra: Jurnal Ilmiah Kependidikan, 1(1), 85-92. https:/ / doi.org/10.37478/jpm.v1i1.354

Copyright Holder :

(C) Yazid, M., \& Atiaturrahmaniah, A., \& Armila, M. (2020).

First Publication Right :

(C) IJoASER (International Journal on Advanced Science, Education, and Religion)

This article is under:

CC BY SA 